\title{
$\mathrm{Al}-\mathrm{Ti}$ 혼합 분말 슬러리를 이용한 강의 알루미나이징처리 방법
}

\author{
이영기 · 김정열 · 이유기 ${ }^{\dagger}$ \\ 위덕대학교 반도체전자공학과
}

\section{Convenient Aluminizing Process of Steel by Using Al-Ti Mixed Powder Slurry}

\author{
Young-Ki Lee, Jung-Yeul Kim and You-Kee Lee ${ }^{\dagger}$ \\ Department of Semiconductor and Electronics Engineering, Uiduk University, Gyeongju, Gyeongbuk 780-713, Korea
}

(2009년 3월 10일 접수 : 2009년 3월 27일 최종수정 : 2009년 3월 27일 채택)

\begin{abstract}
In this study, we attempted to develop a convenient aluminizing process, using Al-Ti mixed slurry as an aluminum source, to control the $\mathrm{Al}$ content of the aluminized layer as a result of a one-step process and can be widely adopted for coating complex-shaped components. The aluminizing process was carried out by the heat treatment on disc and rod shaped S45C steel substrates with Al-Ti mixed slurries that were composed of various mixed ratios (wt\%) of $\mathrm{Al}$ and Ti powders. The surface of the resultant aluminized layer was relatively smooth with no obvious cracks. The aluminized layers mainly contain an Fe-Al compound as the bulk phase. However, the $\mathrm{Al}$ concentration and the thickness of the aluminized layer gradually decrease as the $\mathrm{Ti}$ proportion among Al-Ti mixed slurries increases. It has also been shown that the Al-Ti compound layer, which formed on the substrate during heat treatment, easily separates from the substrate. In addition, the incorporation of $\mathrm{Ti}$ into the substrate surface during heat treatment was not observed.
\end{abstract}

Key words aluminizing process, Al-Ti mixed powder slurry, aluminized layer, Fe-Al compound, Al-Ti compound.

\section{1. 서 론}

차세대 연료전지로 주목받고 있는 용융탄산염 연료전 지의 경우, $650{ }^{\circ} \mathrm{C}$ 의 조업온도에서 40,000 시간 이상 동 안 일정한 출력을 유지하면서 작동되어야 하는 고온 내 구성이 요구된다. ${ }^{1)}$ 그러나 고온에서의 전지 작동시 부식 성이 강한 용융상태의 탄산염 전해질은 이와 접촉하는 전 지몸체 부분을 심하게 부식시켜 전지의 성능을 크게 저 하시켜 용융탄산염 연료전지의 수명 단축을 초래한다. ${ }^{2)}$ 따라서 전지몸체 부분의 부식문제 해결을 위하여 전지 몸 체 재료로 사용하고 있는 스테인레스 강의 표면에 메탈 라이징(metallizing), 클래딩(cladding), 전기도금(electroplating), 팩세멘테이션(pack cementation) 방법 등을 이용 하여 내산화성의 금속막을 피복시키는 표면처리 방법이 적용되고 있다. ${ }^{3-7)}$ 또한 자동차, 전기, 전자산업 등 제조 업의 급속한 발전에 따라 고성능 신소재 개발과 더불어 부품의 성능개선과 제조에 쓰이는 금형 및 공구 등에 있 어서도 이들 재료의 내구성 향상을 위하여 다양한 표면

Corresponding author

E-mail : leeyk@uu.ac.kr (Y.-K. Lee)
처리 공정들이 응용되고 있다. 특히 분말 팩(pack) 알루 미나이징법, 용융 알루미늄 침적법, $\mathrm{PVD}$ 나 $\mathrm{CVD}$ 로 모 소재의 표면에 알루미늄박막을 증착시킨 후, 소정의 온 도에서 일정시간 동안 열처리하여 모소재의 표면에 알루 미늄을 확산 피복시키는 증착확산법 및 플라즈마 질화 처 리 공정을 복합화한 복합표면처리 등의 공정 개발이 국 내·외에서 급속히 활성화되고 있다. ${ }^{8-11)}$ 그러나 용융탄 산염 연료전지용 스테인레스 강과 첨단부품소재 제조에 사용되는 금형 및 공구 등의 성능 개선에 적용되고 있 는 상기의 여러 가지 표면처리 공정들은 알루미늄 확산 피복층의 농도 및 두께를 용이하게 제어할 수 없으므로, 이를 위해서는 2 회 이상의 후속확산열처리나 고가의 증착 설비를 필요로 하기 때문에 처리비용이 상승하게 될 뿐 만 아니라, 처리 공정이 매우 번거롭다는 단점 또한 내 포하고 있다.

본 연구에서는 상기 표면처리 방법들의 단점인 확산피 복층 내의 알루미늄농도 조절 불가능 및 표면 평활도의 저하뿐만 아니라 복잡한 형상에의 적용 곤란 등과 같은 여러 가지 문제점을 해결할 수 있고, 또한 용융탄산염 연 료전지용 스테인레스 강의 부식에 따른 성능 저하의 문 제점 해결과 더불어 첨단부품소재 제조에 사용되는 금형 
및 공구 등에도 적용이 가능한 알루미나이징처리 공정을 개발하고자 한다.

\section{2. 실험 방법}

종래의 알루미나이징처리 방법에 비해 간단하면서도 확 산피복층의 농도 및 두께 제어가 용이할 뿐만 아니라 복 잡한 형상에의 적용이 가능한 알루미나이징처리 방법 개 발을 위하여 원판형 $(\phi=50 \mathrm{~mm}, t=5 \mathrm{~mm})$ 및 봉형 $(\phi=10 \mathrm{~mm}, \quad l=50 \mathrm{~mm})$ 의 $\mathrm{S} 45 \mathrm{C}$ 탄소강을 모소재 (substrate)로 사용하였으며, 원료는 순도 $99.9 \%$, 평균입 도 $3 \mu \mathrm{m}$ 의 $\mathrm{Al}$ 과 순도 $99 \%$, 평균입도 $5 \mu \mathrm{m}$ 의 $\mathrm{Ti}$ 분말 을 각각 사용하였다. 먼저, 이들 분말을 여러 가지 중량 비 $(\mathrm{wt} \%)$ 로 혼합( $\mathrm{Al}: \mathrm{Ti}=10: 0 ~ 1: 9)$ 한 후, 교반기를 이용하 여 이소프로필알코올 $25 \mathrm{ml}$ 당 혼합분말 $10 \mathrm{~g}$ 의 비율로 액상의 슬러리를 제조하였다. 그리고 제조된 액상의 슬 러리를 분사장치에 주입하여 $\mathrm{S} 45 \mathrm{C}$ 탄소강의 모소재 표 면(\#600의 연마지 연마)에 분사시킨 다음, $100{ }^{\circ} \mathrm{C}$ 로 유
지된 건조기내에서 30 분간 유지하여 유기용매를 제거하 였다. 이렇게 준비된 시료는 $8 \times 10^{-4} \mathrm{~Pa}$ 의 압력이 유지된 진공로(vacuum furnace)를 이용하여 열처리 온도를 700 $9500^{\circ} \mathrm{C}$ 까지 승온시켜 30 분 5 시간 동안 알루미나이징 처리를 실시하였다. 그리고 시료의 성분분석 및 구조분 석은 광학현미경, 주사전자현미경(SEM), 전자탐침미세분 석기(EPMA), X-선회절장치(XRD) 및 미소경도계(micro vickers hardness tester) 등을 이용하여 평가하였다.

\section{3. 결과 및 고찰}

Fig. 1(a)는 $\mathrm{S} 45 \mathrm{C}$ 탄소강의 표면에 $\mathrm{Al}$ 과 $\mathrm{Ti}$ 을 7:3의 중량비로 혼합하여 제조한 액상 슬러리를 분사장치를 이 용하여 도포한 후, $100{ }^{\circ} \mathrm{C}$ 로 유지된 건조기내에서 30 분 간 유지시켜 유기용매를 제거한 형상이다. 그리고 Fig. $1(\mathrm{~b})$ 는 $950{ }^{\circ} \mathrm{C}$ 에서 1 시간 동안 알루미나이징처리를 실시 하여 얻어진 $\mathrm{S} 45 \mathrm{C}$ 탄소강의 모소재를 나타낸 것이고, Fig. 1(c)는 알루미나이징처리 후 모소재의 표면에서 박
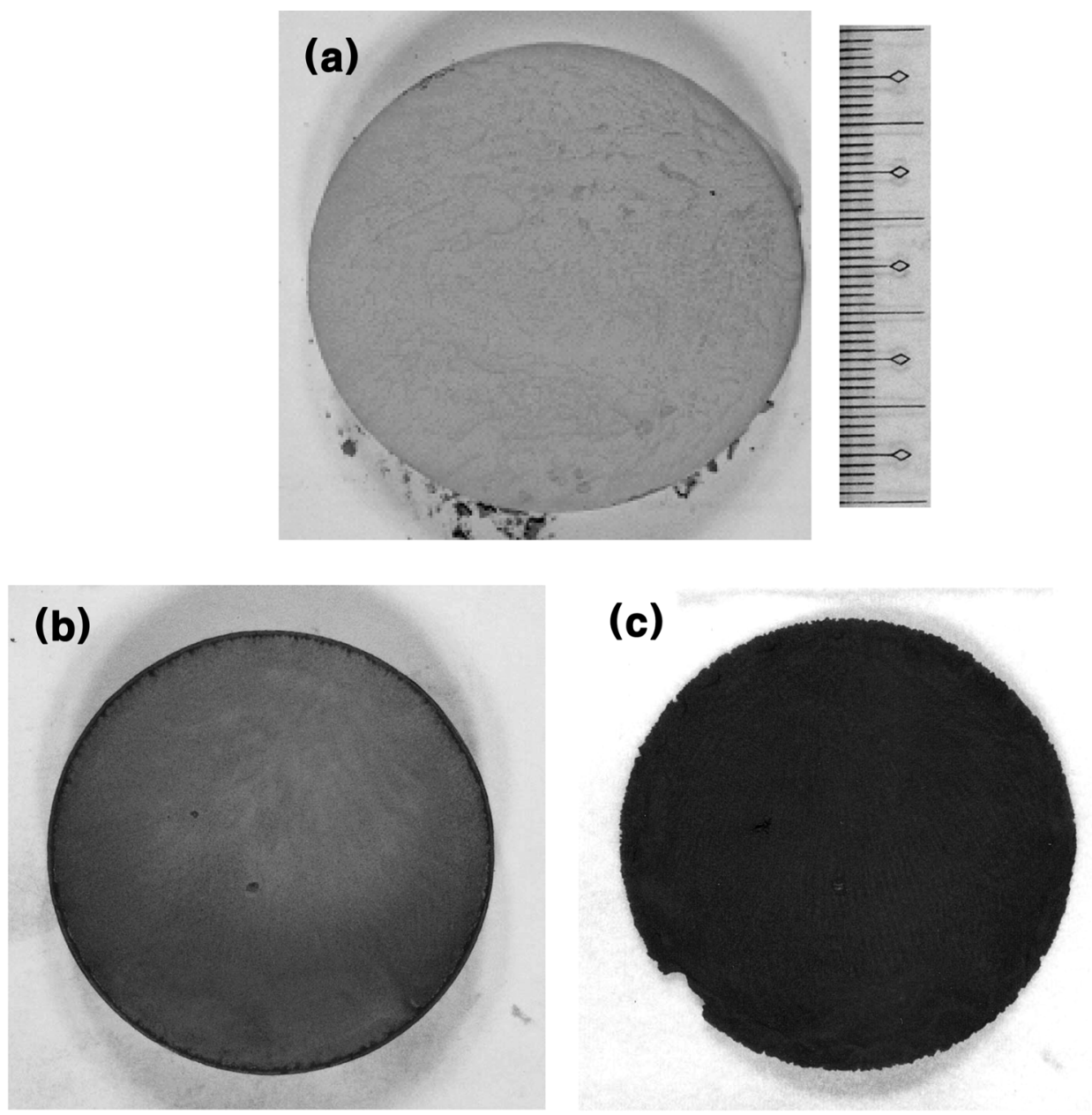

Fig. 1. Typical appearance of (a) sprayed substrate, (b) aluminized substrate and (c) excess peeled layer for disc-shaped $\mathrm{S} 45 \mathrm{C}$ steel aluminized with the slurry of $\mathrm{Al}: \mathrm{Ti}=7: 3$. The aluminizing was carried out in vacuum atmosphere $\left(8 \times 10^{-4} \mathrm{~Pa}\right)$ at $950{ }^{\circ} \mathrm{C}$ for $1 \mathrm{~h}$. One marked as EPL in Fig. 1(c) exhibits the excess layer peeled off from the substrate. 


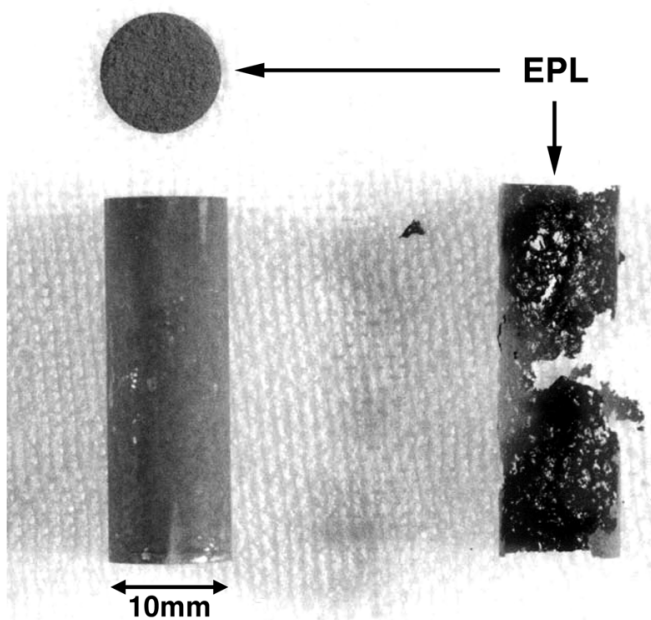

Fig. 2. Typical appearance of rod-shaped S45C steel aluminized with the slurry of $\mathrm{Al}: \mathrm{Ti}=7: 3$. The aluminizing conditions are identical to those in Fig. 1.

리된 물질을 각각 나타낸 것이다. Fig. 1(c)의 그림에서 와 같이 EPL(excess peeled layer)로 표시된 여분의 층 이 원판 모양을 그대로 유지한 채 모소재의 표면으로부 터 쉽게 박리되는 현상을 관찰할 수 있었으며, 이로 인
하여 Fig. 1(c)에서와 같이 모소재의 표면 상태는 평활 한 표면상태를 나타내었다. 그러나 순수 $\mathrm{Al}$ 으로 제조된 슬러리의 경우, 모소재의 표면에 용융된 $\mathrm{Al}$ 의 응집체가 국부적으로 잔존하여 표면상태가 Al-Ti에 비해 평활하지 않았으며, 용융된 $\mathrm{Al}$ 의 응집체 또한 모소재에 강하게 부 착되어 있었다. 이처럼 $\mathrm{EPL}$ 이 모소재로부터 용이하게 박 리되는 것은 열처리중에 확산에 기여하지 않은 과잉의 $\mathrm{Al}$ 과 $\mathrm{Ti}$ 이 반응하여 $\mathrm{Al}-\mathrm{Ti}$ 의 금속간화합물을 형성함으로써 모소재와 반응이 일어나지 않은 결과로 사료되며, XRD 분석 결과 $\mathrm{EPL}$ 은 $\mathrm{Al}_{3} \mathrm{Ti}$ 및 $\mathrm{AlTi}$ 의 금속간화합물로 확 인되었다.

Fig. 2 는 봉상의 $\mathrm{S} 45 \mathrm{C}$ 탄소강에 $950{ }^{\circ} \mathrm{C}$ 에서 1 시간 동 안 알루미나이징처리를 실시한 것으로, 그림에서와 같이 $\mathrm{EPL}$ 이 봉상의 형상을 거의 유지한 채 모소재의 표면으 로부터 박리되었음을 알 수 있다. 이러한 결과는 표면 평 활도의 향상뿐만 아니라 복잡한 형상에의 적용 가능성 등 기존 알루미나이징처리 방법의 단점을 보완할 수 있는 방 법으로 기대된다. 일반적으로 열분사법(thermal spray process)이나 종래의 슬러리법(slurry process)에 의한 모 소재의 경우, 매우 거친 표면 상태를 나나낸다고 알려져 있다. ${ }^{12)}$

Fig. 3은 여러 가지 Al:Ti 조성비의 슬러리를 이용하
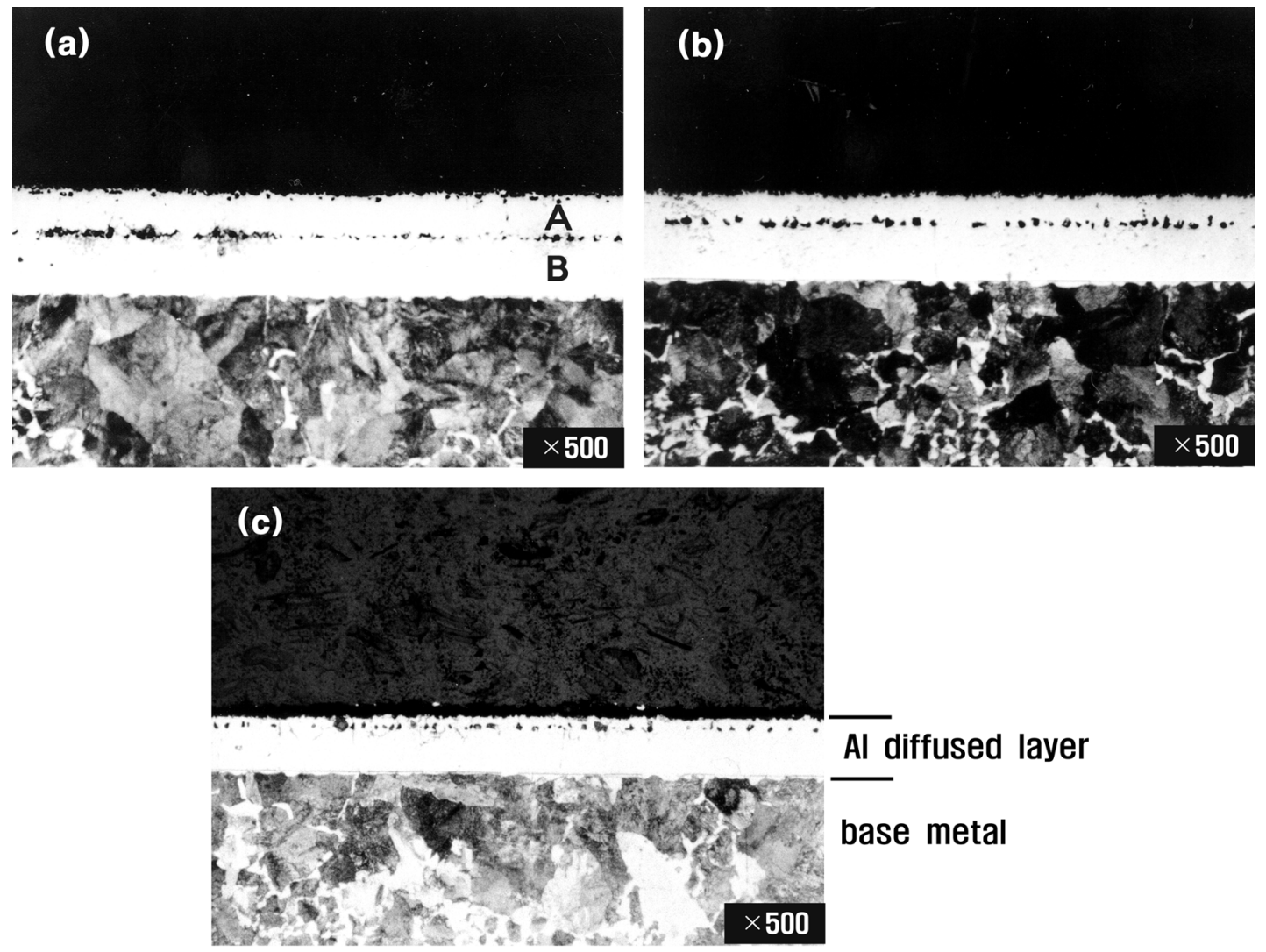

Fig. 3. Cross-sectional morphology of disc-shaped S45C steel aluminized with the slurry of (a) pure Al, (b) $\mathrm{Al}: \mathrm{Ti}=7: 3$, and (c) $\mathrm{Al}: \mathrm{Ti}=5: 5$. The aluminizing was carried out in vacuum atmosphere $\left(8 \times 10^{-4} \mathrm{~Pa}\right)$ at $950{ }^{\circ} \mathrm{C}$ for $1 \mathrm{~h}$. 
여 $950{ }^{\circ} \mathrm{C}$ 에서 1 시간 동안 알루미나이징처리를 실시한 시 료의 단면 미세구조를 나타낸 광학현미경 사진이다. 그 림에서와 같이 모든 조성비에서 확산피복층과 모소재의 기지(matrix)를 뚜렷하게 구분할 수 있으며, 또한 순수 $\mathrm{Al}$ 의 경우 확산피복층의 두께가 $120 \mu \mathrm{m}$ 정도이었으나 Al$\mathrm{Ti}$ 슬러리중의 $\mathrm{Ti}$ 농도가 증가됨에 따라 7:3의 경우 $80 \mu \mathrm{m}, 5: 5$ 의 경우 $60 \mu \mathrm{m}$ 로 확산피복층의 두께가 점점 얇아지고 있음을 알 수 있다. 이는 $\mathrm{Al}-\mathrm{Ti}$ 슬러리중의 $\mathrm{Ti}$ 농도를 조절함으로써 확산피복층의 두께 조절이 가능하 다는 것을 의미한다. 그리고 Fig. 3(a)의 확산피복층에 표 시된 $\mathrm{A}, \mathrm{B}$ 의 경계 부근에서 검게 나타나는 선상의 기 공띠(pore band)를 관찰할 수 있는데 이는 모든 조성비 의 시료에서 관찰되었고, 또한 $\mathrm{Al}-\mathrm{Ti}$ 슬러리 중의 $\mathrm{Ti}$ 농 도가 증가됨에 따라 확산피복층중 $\mathrm{B}$ 층의 두께가 $55 \mu \mathrm{m}$ 로 거의 일정한데 반하여 $\mathrm{A}$ 층의 두께는 점차 얇아지고 있음을 알 수 있다. 이러한 결과는 $\mathrm{Al}$ 의 확산만을 고려 하였을 경우, 모든 $\mathrm{Al}: \mathrm{Ti}$ 조성비에서 $\mathrm{Al}$ 원자의 모소재 로의 확산속도는 $950^{\circ} \mathrm{C}, 1$ 시간의 동일한 열처리조건에 서 거의 동일할 것으로 예측된다. 따라서 $\mathrm{Al}-\mathrm{Ti}$ 슬러리 중의 $\mathrm{Al}$ 이 모소재로 확산되어 형성된 확산피복층은 $\mathrm{B}$ 층 일 것으로 판단된다. 이는 실제로 EPMA 분석결과 확 산피복층의 $\mathrm{A}, \mathrm{B}$ 층에서 $\mathrm{Ti}$ 이 검출되지 않았다는 결과 및 모소재의 표면을 \#1200의 연마지로 연마하였을 경우에 선 상의 기공띠가 관찰되지 않았다는 실험결과로부터 유추 할 수 있었다. 따라서 확산피복층은 $\mathrm{Al}$ 이 모소재로 확 산되어 형성된 $\mathrm{B}$ 층과 모소재의 $\mathrm{Fe}$ 가 슬러리중으로 확산 되어 형성된 $\mathrm{A}$ 층으로 구성되며 $\mathrm{Al}: \mathrm{Ti}$ 조성비가 5:5 이 상, 즉 Ti-rich가 되었을 경우에 $\mathrm{B}$ 층은 거의 관찰되지 않 았다.

Fig. 4는 Fig. 3의 시료들에 대한 확산피복층의 $\mathrm{Al}$ 농

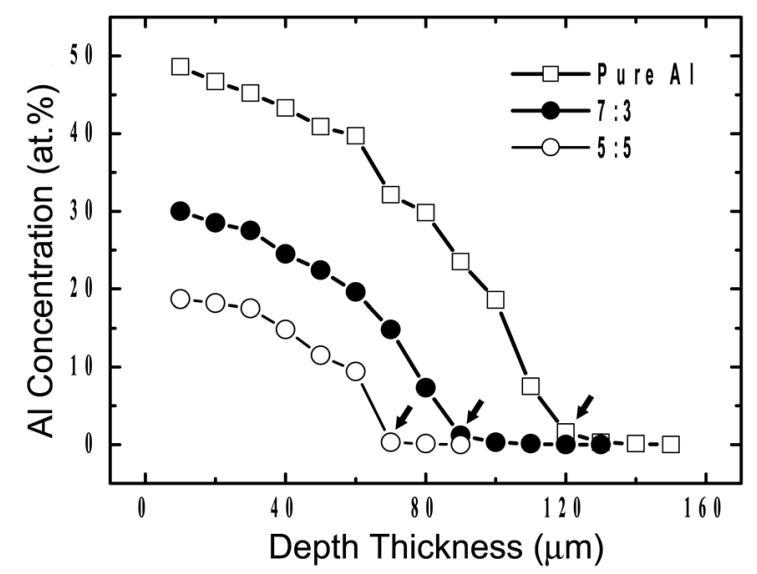

Fig. 4. Cross-sectional Al concentration profiles of disc-shaped $\mathrm{S} 45 \mathrm{C}$ steel aluminized with the various Al:Ti ratio slurries. The aluminizing was carried out in vacuum atmosphere $\left(8 \times 10^{-4} \mathrm{~Pa}\right)$ at $950{ }^{\circ} \mathrm{C}$ for $1 \mathrm{~h}$.

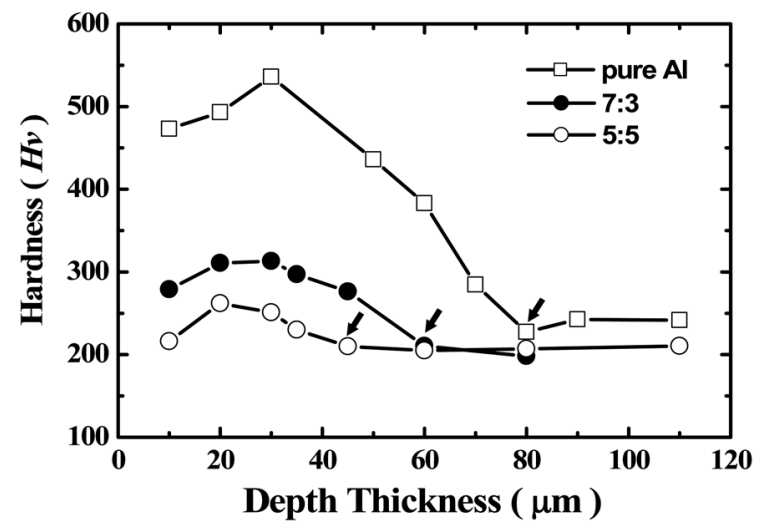

Fig. 5. Cross-sectional micro vickers hardness profiles of discshaped $\mathrm{S} 45 \mathrm{C}$ steel aluminized with the various $\mathrm{Al}$ :Ti ratio slurries. The aluminizing was carried out in vacuum atmosphere $\left(8 \times 10^{-4} \mathrm{~Pa}\right)$ at $950{ }^{\circ} \mathrm{C}$ for $1 \mathrm{~h}$.

도분포를 나타낸 것으로, 그림에서와 같이 확산피복층의 표면으로부터 $10 \mu \mathrm{m}$ 부근에서 $\mathrm{Al}$ 의 농도는 순수 $\mathrm{Al}$ 슬 러리의 경우 대략 $50 \%$ 를 나타내었으나, Al-Ti 슬러리중 의 $\mathrm{Ti}$ 농도가 증가됨에 따라 점차 감소하여 7:3의 경우 $30 \%, 5: 5$ 의 경우 $20 \%$ 를 각각 나타내었다. 그리고 모든 시료들에서 확산피복층의 깊이에 따라 $\mathrm{Al}$ 의 농도가 점 차 감소하였고, 그림에서 화살표로 표시된 확산피복층과 기지의 경계부분, 즉 확산피복층의 전체 두께 또한 $\mathrm{Ti}$ 농 도가 증가됨에 따라 점차 감소하고 있음을 알 수 있다. 그리고 $\mathrm{XRD}$ 분석결과 모든 시료의 확산피복층 $\mathrm{A}, \mathrm{B}$ 에 서 $\mathrm{Al}-\mathrm{Ti}$ 의 2원계 화합물뿐만 아니라 $\mathrm{Al}-\mathrm{Ti}-\mathrm{Fe}$ 의 3 원계 화합물 또한 전혀 검출되지 않았고 단지 $\mathrm{FeAl}$ 상만이 검 출되었으며, EPMA 분석에서도 $\mathrm{Ti}$ 성분은 검출되지 않 았다. 이는 알루미나이징 처리중에 $\mathrm{Ti}$ 이 $\mathrm{Fe}$ 보다 $\mathrm{Al}$ 과 우 선적으로 반응하여 모소재쪽으로 확산되는 $\mathrm{Al}$ 의 농도를 억제함으로써 확산피복층의 농도 및 두께를 조절한 결과 로 판단된다.

Fig. 5는 Fig. 3의 시료들에 대한 확산피복층의 미소 경도를 나타낸 것으로, Fig. 4 의 $\mathrm{Al}$ 의 농도분포와 거의 동일한 거동을 보이며 확산피복층의 깊이에 따라 점차 감 소하는 경향을 보였다. 그리고 그림에서 확산피복층과 기 지의 경계부분인 화살표로 표시된 확산피복층의 전체 두 께 또한 $\mathrm{Al}-\mathrm{Ti}$ 슬러리중의 $\mathrm{Ti}$ 농도가 증가됨에 따라 점 차 감소하였다. 이는 확산피복층의 경도 거동이 주로 $\mathrm{Al}$ 농도에 의존한다는 것을 의미하며, $\mathrm{Al}-\mathrm{Ti}$ 슬러리중의 $\mathrm{Ti}$ 농도를 조절함으로써 확산피복층의 경도 또한 조절이 가 능하다는 것을 시사한다. 이러한 확산피복층의 농도, 두 께, 경도 등에 대한 결과는 $\mathrm{Al}-\mathrm{Ti}$ 슬러리에 포함된 $\mathrm{Ti}$ 의 거동, 즉 $\mathrm{Al}$ 과 $\mathrm{Fe}$ 에 대한 $\mathrm{Ti}$ 의 반응속도 등과 같은 여 러 열역학적 거동과 밀접한 상관관계를 가지는 것으로 예 측된다. 


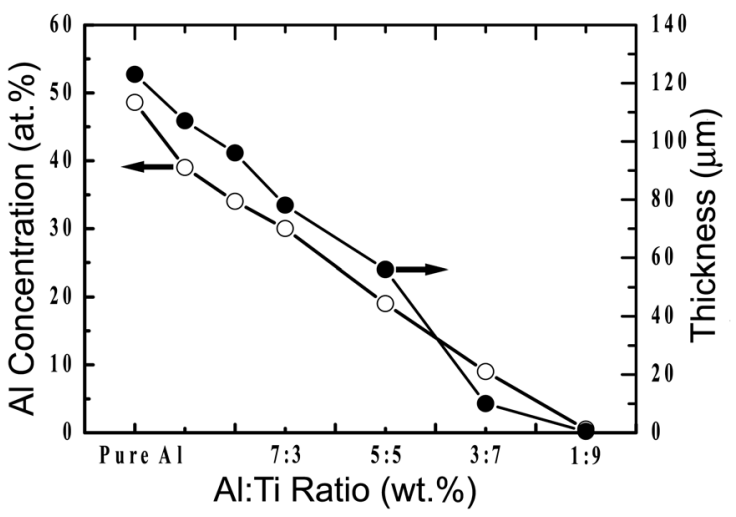

Fig. 6. Al concentration and thickness of the aluminized layer for samples treated with the various Al:Ti ratio slurries. The aluminizing was carried out in vacuum atmosphere $\left(8 \times 10^{-4} \mathrm{~Pa}\right)$ at $950{ }^{\circ} \mathrm{C}$ for $1 \mathrm{~h}$.

Fig. 6은 여러 가지 Al:Ti 조성비의 슬러리를 이용하 여 $950{ }^{\circ} \mathrm{C}$ 에서 1 시간 동안 알루미나이징처리를 실시한 시 료들에 대한 확산피복층의 $\mathrm{Al}$ 농도 및 두께 변화를 종 합하여 나타낸 것이다. 그림에서와 같이 $\mathrm{Al}: \mathrm{Ti}$ 조성비에 따라 확산피복층의 $\mathrm{Al}$ 농도가 거의 직선적으로 감소하 였고, 확산피복층의 두께 또한 거의 직선적으로 감소하 였다. 따라서 본 연구의 Al-Ti 슬러리를 이용한 알루미 나이징처리 방법은 단지 Al:Ti의 조성비만을 변화시킴으 로써 확산피복층의 $\mathrm{Al}$ 농도 및 두께 조절이 용이하고, 또한 액상의 슬러리를 이용하기 때문에 복잡한 형상의 시 료에도 적용이 가능하므로 기존 알루미나이징처리 방법 의 단점을 개선할 수 있는 방법으로 기대된다.

\section{4. 결 론}

본 연구에서는 종래의 알루미나이징처리 방법에 비해 간단하면서도 확산피복층의 농도 및 두께 제어가 용이할 뿐만 아니라 복잡한 형상에의 적용이 가능한 알루미나이 징처리 방법으로 $\mathrm{Al}-\mathrm{Ti}$ 슬러리를 이용한 방법을 검토하 여 다음과 같은 결론을 얻었다.

1. 순수 $\mathrm{Al}$ 으로 제조된 슬러리의 경우, 모소재의 표면 에 용융된 $\mathrm{Al}$ 의 응집체가 국부적으로 잔존하여 표면상 태가 평활하지 않았으나, Al-Ti 슬러리의 경우 모소재의
모양이 그대로 유지된 채 EPL(excess peeled layer) 층 이 모소재의 표면으로부터 쉽게 박리되어 평활한 표면상 태를 나타내었다. 이러한 결과는 원판형 및 봉형 등의 모 소재에서 동일하게 나타났으며, 또한 액상의 슬러리를 이 용하기 때문에 복잡한 형상에의 적용이 가능하다.

2. 확산피복층의 $\mathrm{Al}$ 농도 및 두께 변화는 $\mathrm{Al}: \mathrm{Ti}$ 슬러 리의 조성비에 따라 확산피복층의 $\mathrm{Al}$ 농도가 거의 직선 적으로 감소하였고, 확산피복층의 두께 또한 거의 직선 적으로 감소하였다. 따라서 본 연구의 알루미나이징처리 방법은 $\mathrm{Al}: \mathrm{Ti}$ 의 조성비를 조절함으로써 확산피복층의 $\mathrm{Al}$ 농도 및 두께 조절이 가능하다.

\section{감사의 글}

“연구결과물은 2007학년도 위덕대학교 학술진흥연구비 지원에 의하여 이루어 졌음"

\section{참 고 문 헌}

1. J. R. Selman and H. C. Maru, Physical Chemistry and Electrochemistry of Alkali Carbonate Melts with Special Reference to the Molten-Carbonate Fuel Cell, p.163, Plenum Press (1981).

2. N. Giordano, S. Freno, R. Quagliata, S. Cavallaro and P. Carbonaro, J. Electrochem. Soc., 135, 910 (1988).

3. P. Shen, D. Gan and C. C. Lin, Mater. Sci. Eng., 78, 171 (1986).

4. G. W. Goward and D. H. Boone, Oxid. Met., 3, 475 (1971).

5. P. Tomaszewicz and G. R. Wallwork, Rev. High Temp. Mater., 4, 75 (1978).

6. P. F. Tortorelli and J. H. DeVan, Mater. Sci. Eng., 153, 573 (1992).

7. H. M. Soliman, M. E. Abd and El-Azim, J. Mater. Sci. Technol., 13, 462 (1997).

8. S. Tsuji, J. Jap. Ins. Metals, 59, 726 (1995).

9. H. Glasbrenner, E. Nold and Z. Voss, J. Nuclear Mater., 249, 39 (1997).

10. B. M. Warnes and D. C. Punola, Surf. Coat. Technol., 94, 1 (1997).

11. A. B. Smith, A. Kempster and J. Smith, Surf. Coat. Technol., 120, 112 (1999).

12. J. E. Indacochea, I. Bloom, M. Krumpelt and T. G. Benjamin, J. Mater. Res., 13, 1834 (1998). 